\title{
The Influence of the Composite Resin Material on the Clinical Working Time in Fiberglass Reinforced Periodontal Splints
}

\author{
IONUT LUCHIAN ${ }^{1}$, STEFANA NANU ${ }^{1 *}$, IOANA MARTU ${ }^{1 *}$, \\ MARIA-ALEXANDRA MARTU ${ }^{1 *}$, GIORGIO NICHITEAN ${ }^{1}$, \\ DIANA-CRISTALA KAPPENNERG-NITESCU ${ }^{1}$, GABRIELA GURAU ${ }^{2}$, \\ VICTORITA STEFANESCU ${ }^{2}$, LILIANA PASARIN ${ }^{1}$, MONICA TATARCIUC ${ }^{1}$, \\ SORINA-MIHAELA SOLOMON ${ }^{1}$ \\ "Grigore T. Popa" University of Medicine and Pharmacy, Faculty of Dental Medicine, 16 Universitatii Str., 700115, Iasi, \\ Romania \\ 2"Dunarea de Jos" University of Galati, Faculty of Medicine and Pharmacy, 47 Domneasca Str., 800008, Galati, Romania
}

\begin{abstract}
This study aims to find the most effective method in terms of clinical working time when applying fibreglass splints in the lower frontal group, depending on the type of composite material used. We have selected a group of 30 patients, aged between 50 and 70, with an average age of 57, in the interval March 2016 - June2017. These patients received immobilisations as part of their periodontal treatment, using a system consisting of fibreglass and three different types of composites. The shortest work time was obtained when using the Grandioso heavy flow composite, the next closest time being obtained with Gaenial flow universal. Our study indicated that the highly viscous flow composite resins offers the shortest clinical working time out of all tested materials.
\end{abstract}

Keywords: highly viscous composite resin, periodontal splint, fiberglass reinforced

\section{Introduction}

Periodontal disease is a multi-factor condition that, when not treated properly, determines a progressive decrease of attachment and eventually the loss of teeth. Through a systematic and rigorous control of periodontal inflammation, the teeth affected by periodontal disease can be preserved in the long term, with limited costs, even in those cases in which bone loss is advanced. Bearing in mind the apical displacement of the tooth'scentre of strength in the cases of advanced bone loss, such teeth are often mobile, fact that could have an impact on their mastication and phonation functions and reduce the patients' degree of comfort.

In such cases, splinting these teeth by connecting them to their adjacent neighbours is extremely important, as it reduces their mobility[1,2].

The evolution of the periodontics teeth immobilisation techniques was carried out at the same time with the evolution of the biomaterials which are at the foundation of carrying out this procedure; both the immobilisation splint as well as the dental materials which insure the adhesion is anchored in the non-metallic registry.

The main objective of splinting lower anterior teeth is to reduce the mobility determined by the progression of periodontal disease. Mobility resulting from periodontal inflammation and/or traumatic occlusion can often be treated through proper anti-infectious periodontal therapy and by balancing the occlusion[3-5].

However, the mobility caused by the apical displacement of the tooth's centre of strength and associated with advanced alveolar bone loss, is not very likely to be corrected[6].

The immobilisation of the affected teeth is an option for improving the patients' comfort [7-9] and for ensuring a better control of the occlusion [7].

*email: stefana_nanu@hotmail.com; ioanamartu@gmail.com; alexandra_martu@yahoo.com

All authors had an equal contribution to this article with the one of the first author. 
Nevertheless, especially in the case of severe horizontal bone loss and increased mobility, the decision to preserve or not the affected teeth is a challenging one. This decision must always be made on a case-by-case basis, taking into account the patient's general factors and his or her expectations regarding treatment.

For periodontal splinting we can use external or internal fixed devices, made of composite diacrylic resins, with twined metal threads or with fibreglass [10-12].

\section{Materials and methods}

Our study aims the analysis of the adhesive and biomechanical behaviour of 3 types of current composite biomaterials, used in the periodontics immobilisation technique, structural of each category having a defining role in carrying out the immobilisation especially upon the dental and periodontal stability of the support.

In equal degree, we propose the correlation of the structural aspects and of the behaviour of this bioadhesive behaviour, with an especially important parameter, with a profound impact in improving the dental medical practice, namely the working time.

We included in our study 30 patients that had indication for periodontal splinting at the level of the 5th sextant. We randomly divided the 30 patients into three groups named A, B and C. For the entire study group we used the same fiberglass (Interlig Angelus) and the same bonding agent. Patients included in group A were treated using Grandioso Heavy flow composite (Voco) while patients included in group B were treated using Gaenial flow universal composite (GC). For the patients included in group $\mathrm{C}$ we used Gaenial Posterior composite (GC). Clinical working time is a very important parameter in modern dentistry. The manoeuvres carried out must take as little time as possible, must have increased effectiveness and be durable in time. Of course, this aim is difficult to achieve, but by increasing the practitioner's experience and through the evolution of dental materials, the length of the work stages is reduced and the ergonomic principles are respected.

The working time was calculated using a stopwatch since the rubber dam was applied and until the clinician finished the procedure. All procedures were performed by the same clinician. (Fig. 1-3)

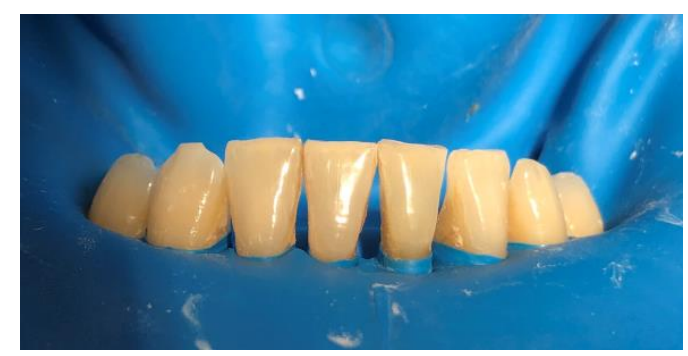

Figure 1. Initial clinical aspect of the $5^{\text {th }}$ sextant

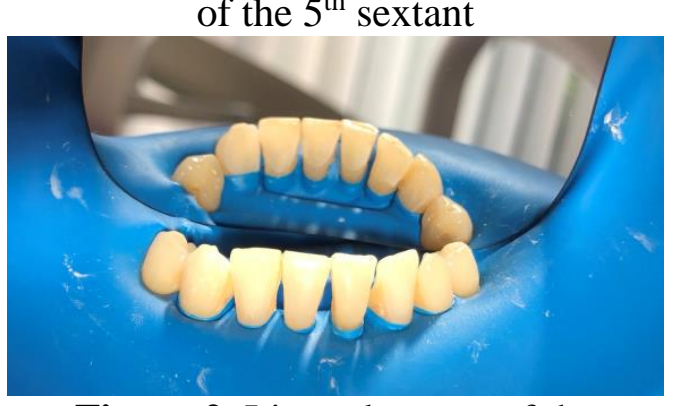

Figure 2. Lingual aspect of the $5^{\text {th }}$ sextant after etching 


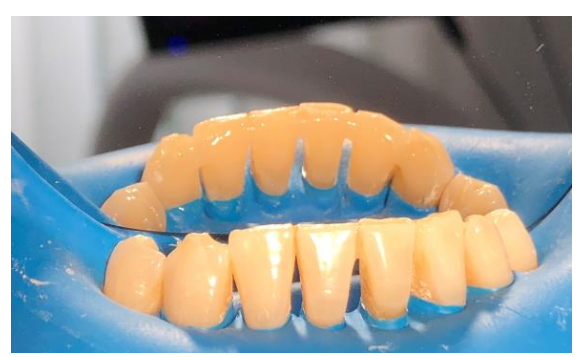

Figure 3. Final clinical aspect of a periodontal splint bonded with a highly viscous flow composite resin

GrandioSO Heavy Flow is a highly viscous nano-hybrid restorative material. GrandioSO Heavy Flow has a much lower contraction during polymerisation $(2.96 \%)$ compared to conventional flow materials, and has high compression and bending strength (417 MPa, and $159 \mathrm{MPa}$, respectively), a very high elastic modulus for a flow material (11.85 GPa), a very tough surface (175 MHV), as well as low abrasion (40 $\mu \mathrm{m}$, ACTA with 200000 cycles). Studies have confirmed that G-aenial Universal Flo has a higher strength, a better resistance towards wearing and a polish retention that is higher than in other tested composites. Newly introduced, it offers higher strength, better aesthetics and manoeuvrability, and combined many of the advantages of fluid and non-fluid composites.

The innovative filling chemistry consists of $200 \mathrm{~nm}$ strontium particles that are silanated a new, proprietary technology, are very dispersed and have a low refraction index. G-aenial posterior is a radioopaque hybrid composite restoration material with a combination of two types of pre-polymerised filling resins. The elastic modulus (Young's modulus) is one measure of a material's elasticity. A material with a high modulus is rigid, whereas a material with a low modulus is flexible. Ideally, a material should not have a very high elastic modulus, as fragile materials are less capable of buffering mastication pressure. G-aenial Posterior shows a similar flexibility to that of most tested composites. Flexible materials have an ability to buffer forces in the areas with high pressure and wear similar to the nanohybrid composite materials.

\section{Results and discussions}

It can be noticed that the lowest values appear in the case of patients in group A, with an average of 6.74 minutes per procedure. These results are followed by the ones recorded in group B with an average value approximately one minute longer ( 7.82 minutes). The values of the clinical working time recorded in the patients from group $\mathrm{C}$ are almost double when compared to the ones from group $\mathrm{A}$ and $\mathrm{B}$. The clinical working time at the level of group $\mathrm{C}$ reached an average of 14.6 minutes. (Table 1)

Table 1.Results of the clinical working time

\begin{tabular}{|c|c|c|c|}
\hline Time(min) & A(HEAVY FLOW) & B(FLOW) & C(SOLID) \\
\hline Patient & 6.80 & 7.30 & 12.40 \\
\hline 1 & 6.70 & 8.20 & 13.20 \\
\hline 2 & 7.20 & 9.10 & 14.50 \\
\hline 3 & 8.00 & 10.10 & 15.20 \\
\hline 4 & 6.40 & 9.40 & 12.40 \\
\hline 5 & 6.20 & 9.30 & 13.40 \\
\hline 6 & & & 15.40 \\
\hline 7 & 6.10 & 9.20 & 16.20 \\
\hline 8 & 6.50 & 8.70 & 16.80 \\
\hline 9 & 6.70 & 8.80 & 17.30 \\
\hline 10 & 6.80 & 8.90 & 14.68 \\
\hline Average work time & 6.74 & 7.82 & 1.7862 \\
\hline Standard deviation & 0.5460 & 0.7512 & 12.4 \\
\hline Minimum value & 6.1 & 7.3 & 17.3 \\
\hline Maximum value & 8 & 10.1 & \\
\hline
\end{tabular}


The shorter clinical working time is achieved due to the characteristics of materials, because flow composites are applied directly from the syringe and require a shorter trimming and polishing time, due to the fact that they have fewer irregularities after photo polymerisation. (Fig. 4)

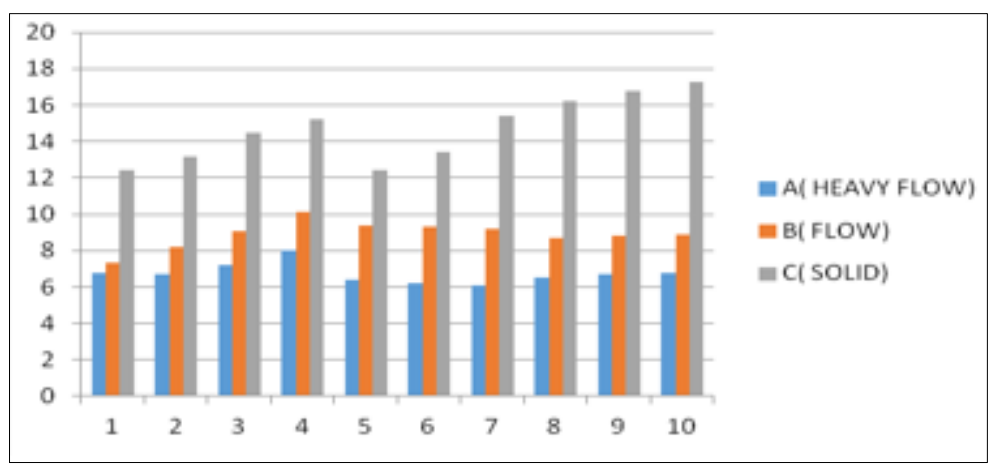

Figure 4. Comparative results in the three groups

In the case of solid composites, the composite is applied on the splint using a spatula, fact that increases the working time, as it is difficult to appreciate the thickness with precision.

Sometimes, lengthy use of a certain type of material creates additional comfort for the practitioner and improved clinical working times. Therefore, the time values obtained may be influenced by the practitioner's experience in using that particular type of material.

Sfondrini et al. tested the flexural strengths differences between conventional and nanofilled fiberreinforced composites[13]. Further clinical studies can be conducted in order to conclude if the use of conventional versus nanofilled fiber reinforced composites can influence the clinical working time[1,2].

The importance of monitoring clinical working time has not been highlighted in many previous scientific studies. The main focus has been on the periodontal splinting' durability and efficiency over time, rather than on the time allotted to the actual operations[14,15].

Modern dental medicine must also focus on the time allotted to certain procedures, the trend being towards optimising the time/quality ratio and increase the comfort of the patient.

Scribante et al. show as well that splints can be easily repaired, so in many cases it is not necessary to completely debond the framework with the substitution with a new one[16].

Khan et al. concluded in a systematic review that glass fiber reinforced composites have emerged as a major class of structural material and are either used or being considered as substitutes for traditional materials in dental applications[1,2,17].

Other studies emphasized that the selection of the splint and of the type of fibreglass suitable for the procedure is made based on the advantages, disadvantages and individual clinical experience[18]. The same study pointed out that the ideal immobilisation system must be designed in such a way that will retain a minimal amount of bacterial plaque, will allow maintenance in the long term, will be able to fulfil the assigned function and will not interfere with occlusion or with phonetics[18].

\section{Conclusions}

Our study indicated that the highly viscous flow composite resins offers the shortest clinical working time out of all tested materials.

Using this type of composite resins might be a reliable solution to reduce the clinical working time when applying fiberglass reinforced periodontal splints.

\section{References}

1.TANCULESCU, O., DOLOCA, A., VIERIU, RM., et al., Rev. Chim.(Bucharest), 67, no.1, 2016, p. 96-112. 
2.VIERIU, R.M., TANCULESCU, O., MOCANU, F., et al.,Rev .Chim., 52, (2), 2015, 266-271 3.LUCA, O.E., MARTU, I., LUCHIAN, I., LUCA, E., VIRVESCU, D., ANDRONACHE, V., TATARCIUC, M., MARTU, S., Rom. J. of Medical and Dental Education, 2019, 8, no. 8, pp. 51-55 4.IOANID, N., IFTENI, G., GRADINARU, I., MARTU, S., TANCULESCU,O., Rom. J. of Oral Rehab., 2016, 8, no.2, pp.111-114.

5.IFTENI, G., APOSTU, A., TANCULESCU, O., Rom. J of Oral Rehab., 2016,8, no.2, pp.94-100 6.LUCHIAN, I., VATA, I., MARTU, I., TATARCIUC, M., PENDEFUNDA, V., MARTU, S., Rom. J. Oral Rehab., 2016, 8, no.1, pp. 80-83.

7.GRAETZ, C., DÖRFER, CE., KAHL, M., KOCHER, T., FAWZY EL-SAYED, K., WIEBE, JF., GOMER, K., RÜHLING, A., J.Clin.Periodontol.2011, 38,pp. 707-714

1. 8.SONNENSCHEIN, S.K., BETZLER, C., RUTTERS,M.A., KRISAM, J., SAURE, D., KIM, T.S., ActaOdontol. Scand., 2017, pp. 1-8.

9.WU, X.Y., ZHONG, Q., Shanghai Kou Qiang Yi Xue. 2014,23, no.2, pp. 204-208

10.CIOCAN-PENDEFUNDA, A.A., MARTU, M.A., ANTOHE, M.E., LUCHIAN, I., MARTU, I., SIOUSTIS, I., IFTENI, G., Rom J. of Oral Rehab., 2018, 10, no. 4, pp. 91-95

11.GRADINARU, I., ANTOHE, M.E.,HURJUI, L.L., Rom J of Oral Rehab,2018, 10, no.1, pp.114119

12.BOLAT, M., STOLERIU, S.,NICOLETA, T., et al.Rom J of Oral Rehab, 2017, 9, no. 3, pp.30-34

13.SFONDRINI, M.F., MASSIRONI, S., PIERACCINI, G., SCRIBANTE, A., VALLITTU, P.K., LASSILA, L.V., GANDINI, P., Dent. Traumatol., 2014,30, pp.32-35

14.VALLITTU, P.K., Dent. Mater. J., 2014,2417, pp. 1-7

15.SCRIBANTE, A., VALLITTU, P.K., OZNAN, M., Biomed Res. Int., 2018, pp.1-2

16.SCRIBANTE, A., VALLITTU, P.K., OZNAN, M., LASSILA, L.P.V., GANDINI, P.,

SFONDRINI, M.F., Biomed Res. Int., 2018, pp.1-8

17.KHAN, A.S., AZAM, M.T., KHAN, M., MIAN, S.A., REHMAN, I.U., Mater. Sci. Eng. C., 2015, 47, pp. 26-39

18.LUCHIAN, I., NANU, S., MARTU, I., TEODORESCU, C., PASARIN, L., SOLOMON, S., MARTU, M.A., TATARCIUC, M., MARTU, S., Rom. J. Oral Rehab., 2018, 10, no.2, pp. 63-69

Manuscript received: 4.03.2020 